\title{
Electroforming Repair of a Nozzle Approach Section
}

H. R. Johnson, J. W. Dini

Prepared by Sandia Laboratories, Albuquerque New Mexico 87115

and Livermore, California 94550 for the United States Eneriy Research

and Development Administration under Contract AT (29-1) 789

Printed August 1976

When printing a copy of any digitized SAND Report, you are required to update the markings to current standards. 
Issued by Sandia Laboratories, operated for the United States Energy Research and Development Administration by Sandia Corporation.

\section{NOTICE}

This report was prepared as an account of work sponsored by the United States Government. Neither the United States nor the United States Energy Research and Development Administration, nor any of their employees, nor any of their contractors, subcontractors, or their employees, makes any warranty, express or implied, or assumes any legal liability or responsibility for the accuracy, completeness or usefulness of any information, apparatus, product or process disclosed, or represents that its use would not infringe privately owned rights. 
SAND76-8031

Unlimited Release

Printed August 1976

ELECTROFORIVING REPAIR OF A NOZZLE APPROACH SECTION

\author{
H. R. Johnson \\ J. W. Dini \\ Metallurgy and Electroplating Division 8312 \\ Sandia Laboratories
}

\begin{abstract}
Procedures were developed to repair by nickel plating the approach section of the $2.44-\mathrm{m}$ (8-foot) HTST combustor from Langley Research Center. A $20.3-\mathrm{cm}(8-\mathrm{inch})$ diameter test part fabricated by using the same procedures that were used for the full-size part showed good integrity and, when subjected to burst test, did not fail until it reached 55 $\mathrm{MN} / \mathrm{m}^{2}$ (8000 $\left.\mathrm{psi}\right)$. This was a good indication that the repair procedure would be adequate for the full-size nozzle section, since intended operating pressure is only $3.4 \mathrm{MN} / \mathrm{m}^{2}$ (500 psi). The repair process consisted of wedging aluminum strips over exposed open channels in the steel substrate and then cleaning, activating, and nickel-plating the region in need of repair. The key to the process was the use of a nickel sulfamate-sulfamic acid solution to prepare the nickel in the region of the repair zone for reception of the nickel plating without attacking the aluminum strips. Ring shear tests were used to check adhesion of the nickel plating. After completion of the plating, the part was subjected to a hydrostatic pressure of $3.4 \mathrm{MN} / \mathrm{m}^{2}$ (500 psi) and evidenced no signs of failure.
\end{abstract}




\section{ACKNOW LEDGMENTS}

A number of people contributed to the work described in this report. The authors would particularly like to acknowledge the support of the following Sandia personnel: M. J. Nash, D. E. Brown, and J. R. Helms, Metallurgy and Electroplating Division 8312, plating; W. Young, Model Labs and Inspection Division 8423, machining; L. A. Brown, Material Characterization Division 8314, testing; T. L. Bryant, 8312, metallography, and C. Verity, Technical Publication and Art Division, 8265, technical editing. G. D. Ware of NASA Langley provided program direction and many helpful discussions. 


\section{CONTENTS}

$\underline{\text { Page }}$

$\begin{array}{ll}\text { Introduction } & 11\end{array}$

$\begin{array}{ll}\text { Scope of Work } & 13\end{array}$

$\begin{array}{lr}\text { Phase } 1 \text { - Fabrication of a Test Part } & 13\end{array}$

$\begin{array}{ll}\text { Plating on SA } 106 \text { Steel } & 14\end{array}$

$\begin{array}{ll}\text { Description of Process for Test Part } & 16\end{array}$

$\begin{array}{ll}\text { Evaluation of the Test Part } & 18\end{array}$

Phase 2 - Repair of Full-Size Part 19

$\begin{array}{ll}\text { As-Received Condition } & 19\end{array}$

$\begin{array}{ll}\text { Repair Process } & 19\end{array}$

Procedure for Cleaning and Nickel Plating $\quad 26$

of Nozzle 


\section{ILLUSTRATIONS}

Figure

Page

1. Combustor Nozzle With Incisions in Nickel Skin

2. SA106 Seamless Pipe Ring Shear Specimens and Die Used for Testing

3. Test Part in Various Stages of Preparation

4. Test Part After Burst Testing

5. Close-up View of Combustor Showing Channels Not Opened by Machining

6. Aluminum Shims Wedged in Channels to Be Repaired by Plating

7. View of Part Showing Plastic Bottom Plug and Extension Ring

8. Interior of Part Before Filling With Plating Solution

9. Side View of Part Before Filling With Plating Solution

10. View of Part During Plating

11. Stop-off Lacquer Removed From Part 


\title{
ELECTROFORIMING REPAIR OF A NOZZLE APPROACH SECTION
}

\author{
Introduction
}

Because Sandia Laboratories, Livermore (SLL) had successfully developed a procedure for electroforming nickel skins on channeled nozzle structures $^{1}$ for NASA Langley Research Center (LRC) in 1975, LRC recently contracted with SLL to solve a related problem. The approach section of an LRC 2. 44-m (8-ft) HTST combustor nozzle (drawing number LD-524204) had been fabricated in part by nickel plating. The vendor who did the plating used wax to fill the coolant flow channel cavities in the nozzle and, when the plating had been completed, discovered that much of the wax could not be removed by either heating or solvent. Personnel at LRC also were unsuccessful in their attempts to remove the wax until they made incisions about $2.54 \mathrm{~cm}$ ( 1 in. ) wide in the nickel to expose portions of the cavities and removed the wax by reaming. These incisions (see Figure 1) then had to be repaired with nickel.

On the earlier project for LRC, SLL had developed a process which consisted of wedging aluminum strips into nozzle channels, plating nickel to a specified thickness, dissolving the aluminum by passing caustic solution through the channels, and then machining to final tolerance. A 15-by-66-cm (6-by-26-in.) section of a nozzle was fabricated at Sandia with this process and was then burst-tested at LRC. Results were very encouraging. All channels were shown to be open and the nickel deposit was of good quality. When the part was hydrostatically tested, failure did not occur until the pressure reached $24.2 \mathrm{MN} / \mathrm{m}^{2}(3500 \mathrm{psi})$ and then in the stainless steel and not in the plating; intended operating pressure for this part is $3.4 \mathrm{MN} / \mathrm{m}^{2}$ (500 psi). It was on the basis of these results that LRC contracted with Sandia to repair the nozzle approach section with nickel plating.

${ }^{1}$ J. W. Dini and H. R. Johnson, Electroformed Channeled Nozzle Structures - Procedures and Property Data, Sandia Laboratories, SAND75-8030, to be published. 


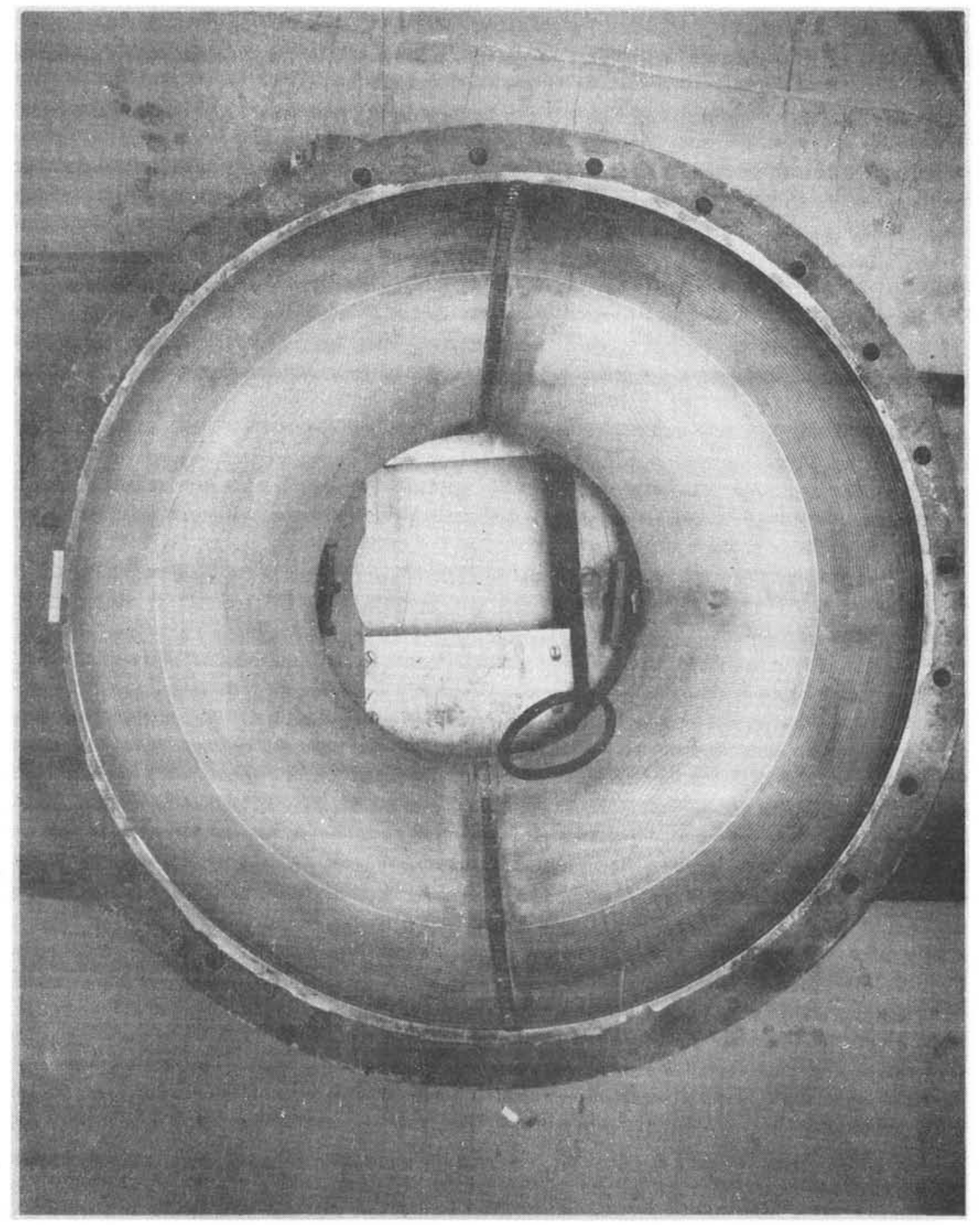

Figure 1. Combustor Nozzle With Incisions in Nickel Skin 
Scope of Work

The work consisted of two phases:

1. Fabrication of a $20.3-\mathrm{cm}$ (8-in.) diameter test part for evaluation at LRC

2. Repair of the full-size combustor once it had been demonstrated that the test part successfully met all LRC requirements

Phase 1 - Fabrication of a Test Part

The objectives of this portion of the program were to fabricate a small part using the same material and procedures that would be used on the fullsize part and then to test this small part to destruction. The full-size nozzle had been machined from a casting of ASTM A-216 grade WCB steel, but none of this material was available for the test part. Therefore, SA 106 grade B seamless pipe, which is very close in composition to the casting material, was used. Table I compares the composition of these two materials.

TABLE I

COMPOSITION $^{(1)}$ OF ASTM A-216 GRADE WCB CASTING AND SA 106 GRADE B SEAMLESS PIPE

\begin{tabular}{lccc}
\hline & ASTM A-216 Grade WCB & SA 106 Grade B \\
\cline { 2 - 2 } Carbon & 0.30 & 0.30 \\
Manganese & 1.0 & 1.0 \\
Phosphorus & 0.04 & 0.048 \\
Sulfur & 0.045 & 0.056 \\
Silicon & 0.60 & 0.10 \\
Iron & Balance & Balance \\
\hline
\end{tabular}

(1) In weight percent 


\section{Plating on SA 106 Steel}

The first step in this part of the program was to make sure that nickel could be adherently plated on the SA 106 steel. Although Sandia had developed procedures for plating on nozzles with aluminum inserts during the previous work for LRC, the process had to be checked with SA 106 steel, since the earlier program had used a different substrate material, namely 405 stainless steel. Therefore, ring shear tests were used to measure the bond strength of nickel plated on SA 106. The tests were performed by plating on a 3/4-inch seamless rod and then machining rings for testing. The machined samples were forced through a hardened steel die with a hole larger in diameter than the unplated rod but smaller in diameter than the plated rod. Some specimens and the test die are shown in Figure 2.

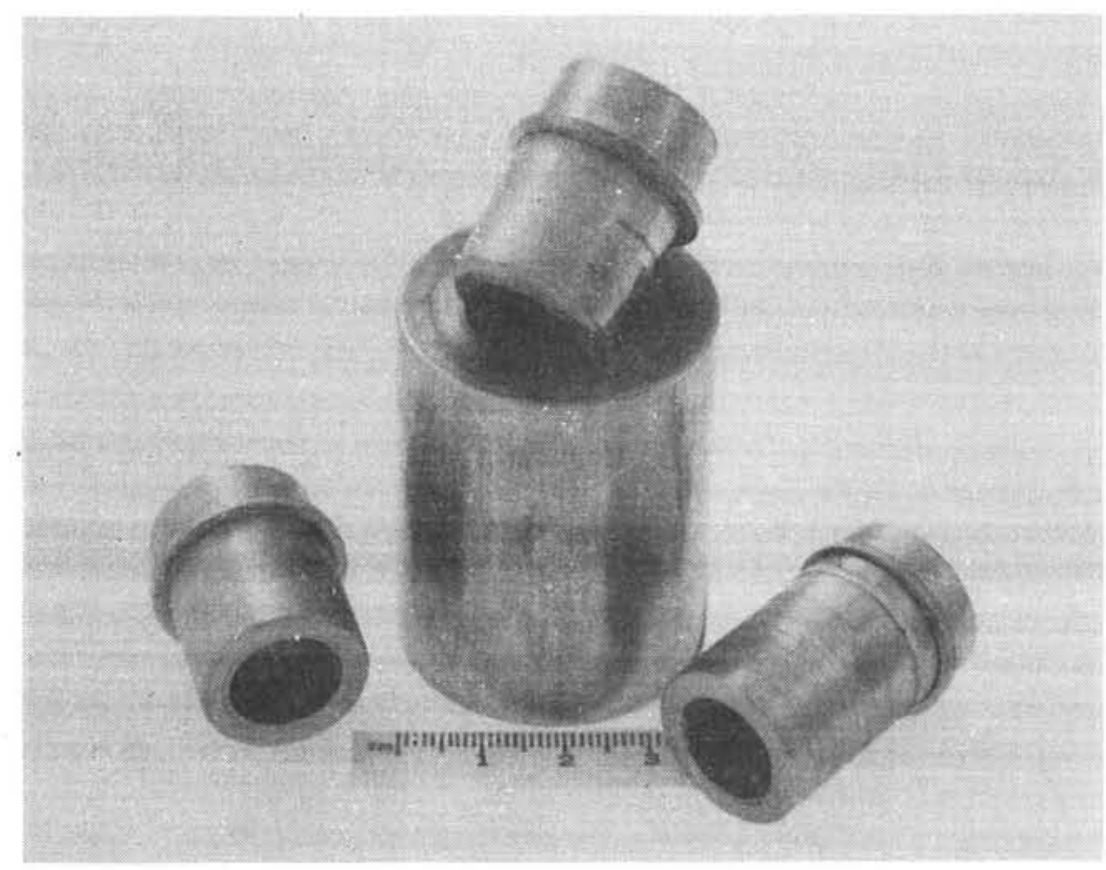

Figure 2. SA106 Seamless Pipe Ring Shear Specimens and Die Used for Testing

The procedure that had worked well under the previous contract consisted of anodic treatment in sulfuric acid solution, followed by cathodic treatment in a highly acidified nickel sulfamate strike. This latter step was the key to the process, since it allowed for deposition of an adherent nickel film on the nickel and stainless steel substrates without attacking the aluminum strips that were wedged in the channels. Variations of these steps were checked with the SA 106 rods. Results in Table II show that all treatments included in the test program provided acceptable adhesion; however, the best results were obtained when the sulfuric acid was more concentrated (the first process listed in Table II). Therefore, this treatment was chosen for use with the $20.3-\mathrm{cm}(8-\mathrm{in}$.$) diameter test part.$ 
TABLE II

RING SHEAR DATA FOR NICKEL-PLATED SA 106 GRADE B SEAMLESS PIPE

\begin{tabular}{|c|c|c|}
\hline \multirow[t]{2}{*}{ Cleaning/Activating Procedure } & \multicolumn{2}{|c|}{ Ring Shear Strength ${ }^{\mathrm{C}}$} \\
\hline & $\mathrm{MN} / \mathrm{m}^{2}$ & psi \\
\hline $\begin{array}{l}\text { Clean, }{ }^{d} \text { anodic-treat in } 400 \mathrm{ml} / 1 \text { sulfuric acid at } \\
1080 \mathrm{~A} / \mathrm{m}^{2} \text { for } 3 \text { minutes, sulfamate nickel-strike } \\
\text { at } 535 \mathrm{~A} / \mathrm{m}^{2} \text { for } 5 \text { minutes, nickel-plate }\end{array}$ & 282 & 40900 \\
\hline $\begin{array}{l}\text { Clean, anodic-treat in } 100 \mathrm{ml} / 1 \text { sulfuric acid at } \\
1080 \mathrm{~A} / \mathrm{m}^{2} \text { for } 3 \text { minutes, sulfamate nickel-strike } \\
\text { at } 535 \mathrm{~A} / \mathrm{m}^{2} \text { for } 5 \text { minutes, nickel-plate }\end{array}$ & 219 & 31800 \\
\hline $\begin{array}{l}\text { Clean, anodic-treat in sulfamate nickel-strike at } \\
535 \mathrm{~A} / \mathrm{m}^{2} \text { for } 3 \text { minutes, cathodic-treat in same } \\
\text { solution at } 268 \mathrm{~A} / \mathrm{m}^{2} \text { for } 5 \text { minutes, nickel-plate }\end{array}$ & 232 & 33700 \\
\hline \multicolumn{3}{|c|}{$\begin{array}{l}{ }^{a} \text { Composition (in wt } \% \text { ) of this material is } 0.30 \mathrm{C}, 1.0 \mathrm{Mn}, 0.048 \mathrm{P}, 0.056 \\
\mathrm{~S} \text { and } 0.10 \mathrm{Si} \text {. }\end{array}$} \\
\hline \multicolumn{3}{|c|}{${ }^{\mathrm{b}}$ Shear strength of SA 106 steel is $383 \mathrm{MN} / \mathrm{m}^{2}$ (55 $800 \mathrm{psi}$ ). } \\
\hline \multicolumn{3}{|c|}{${ }^{\mathrm{c}}$ All reported values are the average of 4 tests. } \\
\hline \multicolumn{3}{|c|}{$\begin{array}{l}\mathrm{d}_{\text {The cleaning cycle included degreasing in solvent and then anodically }} \\
\text { cleaning in hot alkaline solution. }\end{array}$} \\
\hline \multicolumn{3}{|c|}{$\begin{array}{l}\mathrm{e}_{\text {The sulfamate nickel strike contained } 80 \mathrm{~g} / 1 \text { nickel (as nickel sulfamate) }} \\
\text { and } 150 \mathrm{~g} / 1 \text { sulfamic acid; temperature was } 49 \mathrm{C} \text {. }\end{array}$} \\
\hline
\end{tabular}


A part was fabricated from SA 106 steel (Figure 3a), according to LRC specifications. Groove width was $0.50 \mathrm{~cm}$ (0.200 in.); groove depth was $0.34 \mathrm{~cm}$ (0.135 in. ); and land width was $0.30 \mathrm{~cm}(0.120 \mathrm{in}$.). Aluminum strips, $0.76 \mathrm{~mm}$ (0.030 in.) thick, were used to seal the channels (Figure $3 \mathrm{~b}$ ) prior to cleaning, activating, and plating with nickel. After the nickel had been machined to a thickness of $1.52 \mathrm{~mm}(0.060 \mathrm{in}$.), the aluminum strips were dissolved by circulating caustic solution through the channels, and two incisions were made 180 degrees apart in the nickel to expose the steel (Figure 3c). The taper on the nickel sections of these cuts was 30 degrees, and about $1.27 \mathrm{~cm}(1 / 2 \mathrm{in}$.) of channel width was exposed at the bottom of each cut. Aluminum u-shims were then used to plug the channels (Figure 3d), the part was cleaned, plated with nickel in the regions of the cuts, and then machined to a final thickness of $1.02 \mathrm{~mm}(0.040 \mathrm{in}$. ) of nickel plating (Figure $3 \mathrm{e}$ ).

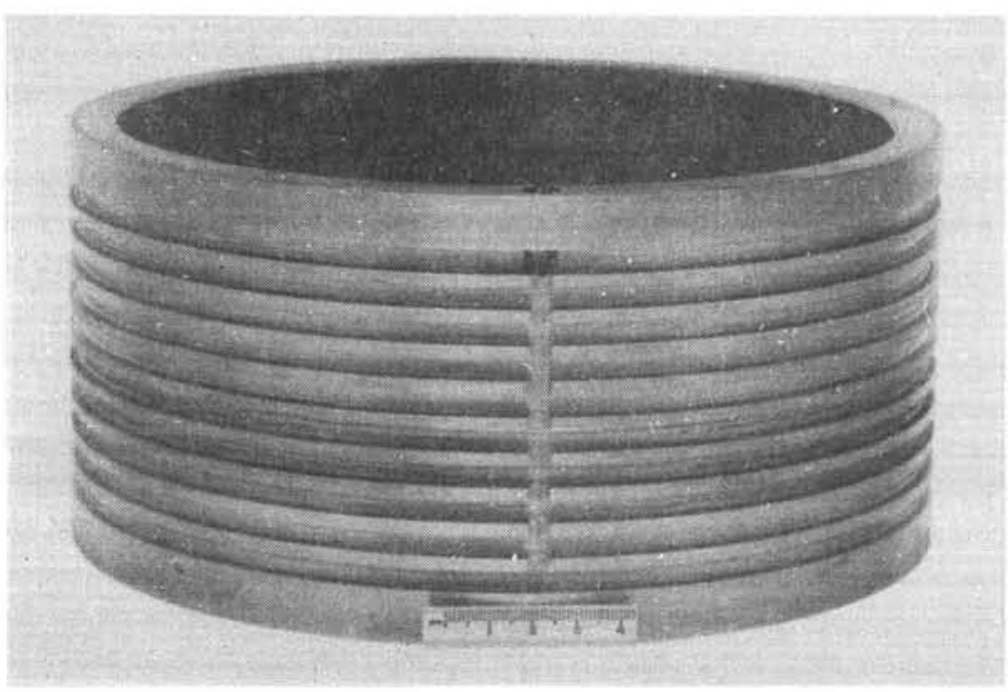

a. Test part after machining

b. Aluminum strips over wedged channels in test part

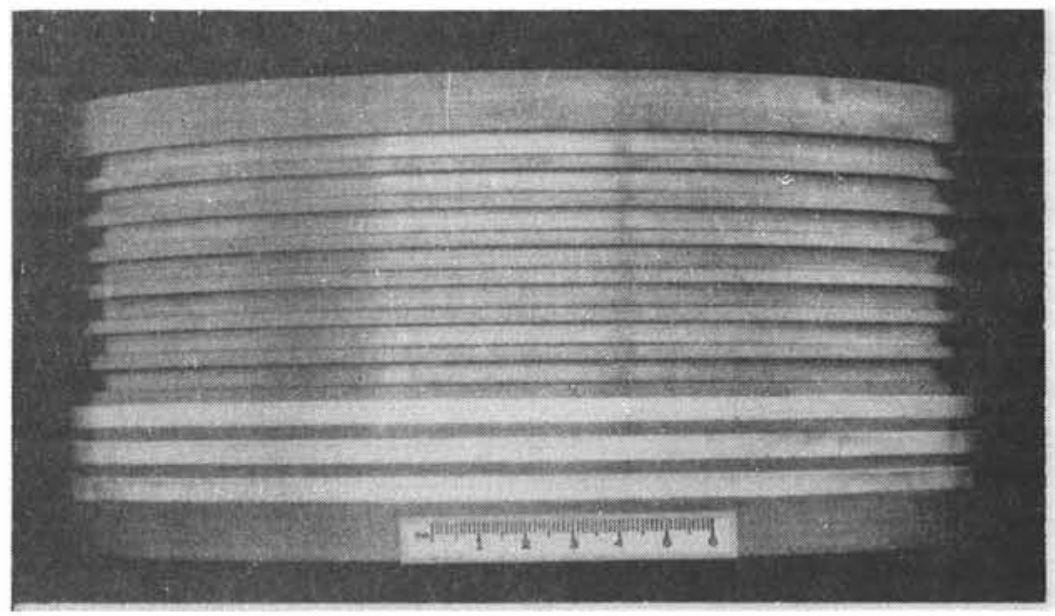

Figure 3. Test Part in Various Stages of Preparation 


\section{c. Beveled incisions made in}

the nickel plating

d. Aluminum shims wedged over exposed channel areas
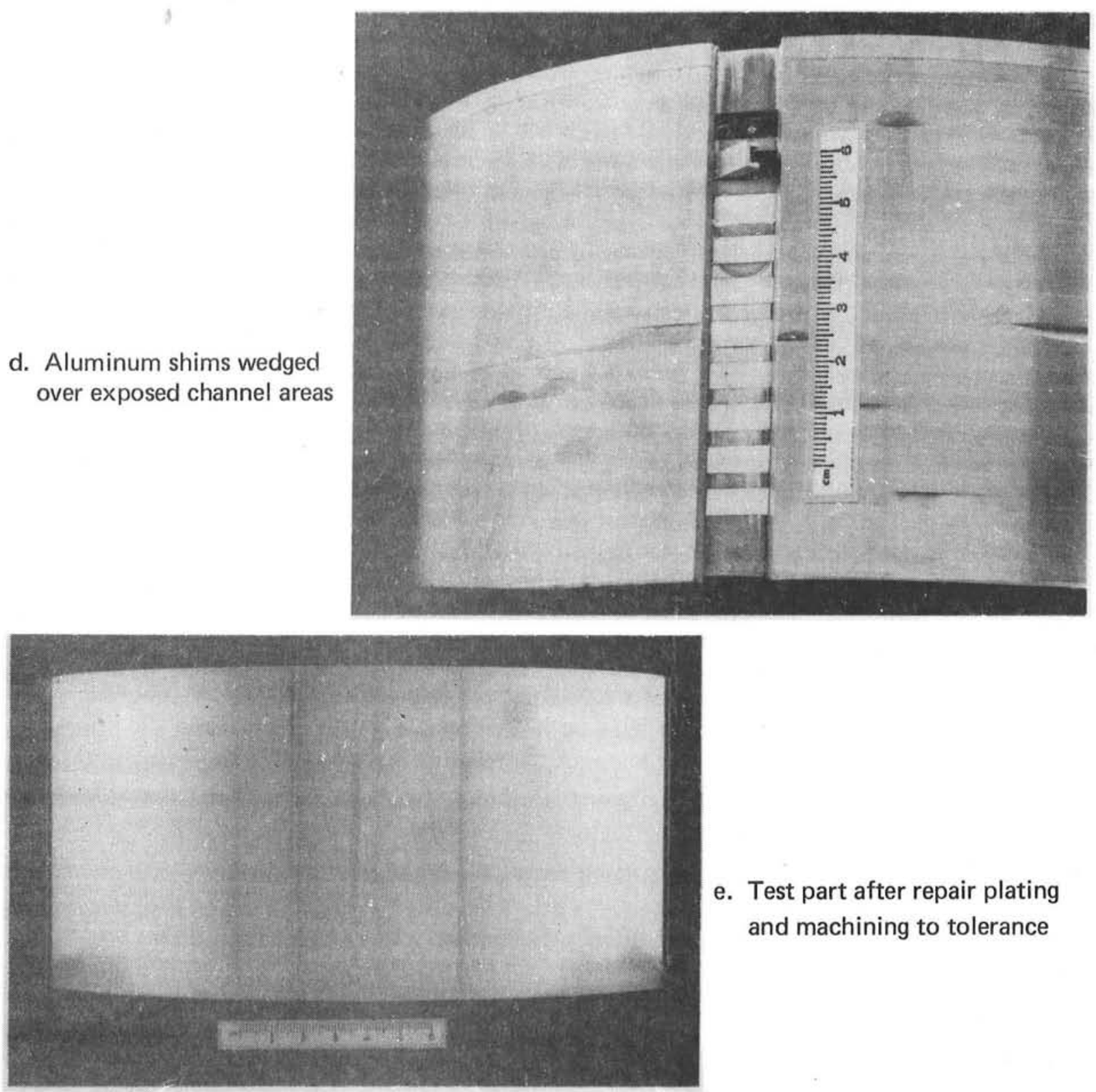

e. Test part after repair plating and machining to tolerance 
The part was submitted to a pressure of $3.4 \mathrm{MN} / \mathrm{m}^{2}(500 \mathrm{psi})$ for 30 minutes in the high pressure lab at Sandia, since this is the intended operating pressure on the full-size nozzle section. No evidence of failure was noted; therefore the part was shipped to LRC for further evaluation. At LRC the part was first given an intensive nondestructive evaluation. Ultrasonic "C" scan data indicated a high-strength bond with no disbonds. The appearance of the bond was uniform throughout the part and of apparent high quality. The part was then hydrostatically tested until it eventually failed at a pressure of $55 \mathrm{MN} / \mathrm{m}^{2}(8800 \mathrm{psi})$. Failure occurred in the nickel after it had yielded (see Figures $4 a$ and $b$ ). No evidence of failure was noted in the repaired regions or between the nickel plating and the SA 106 substrate material. LRC personnel were quite pleased with this result, since it provided a theoretical safety factor of 16, based on an operating pressure of $3.4 \mathrm{MN} / \mathrm{m}^{2}$ (500 psi). Therefore, the decision was made to repair the fullsize part by using the same procedures that had been used on this $20.3-\mathrm{cm}$ (8-in.) diameter part.

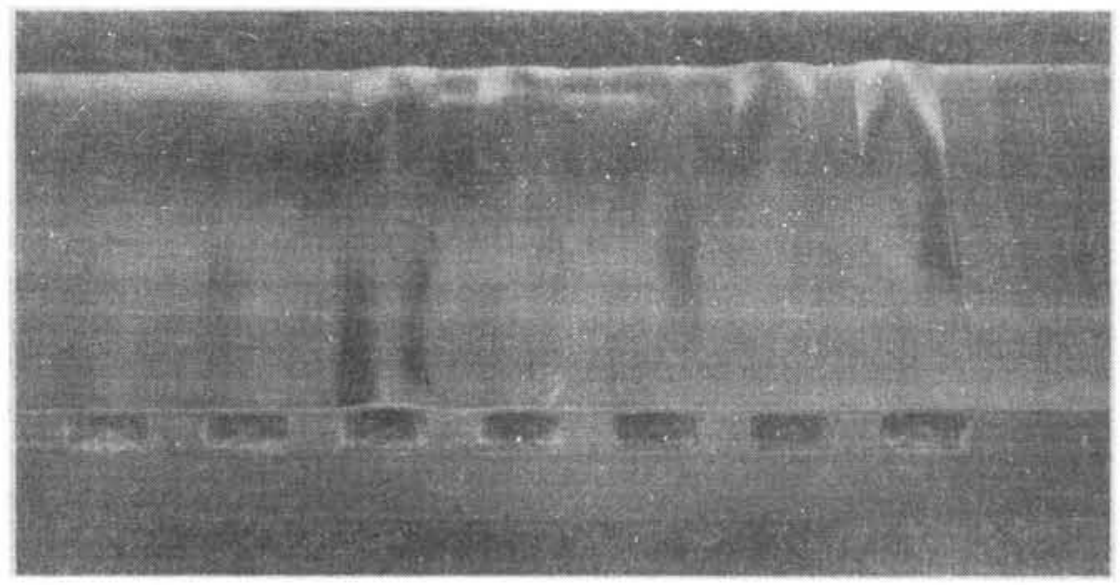

a. Section of 20.3-cm part after burst testing

$1.5 \times$

b. Close-up view of section shown in Figure 4a

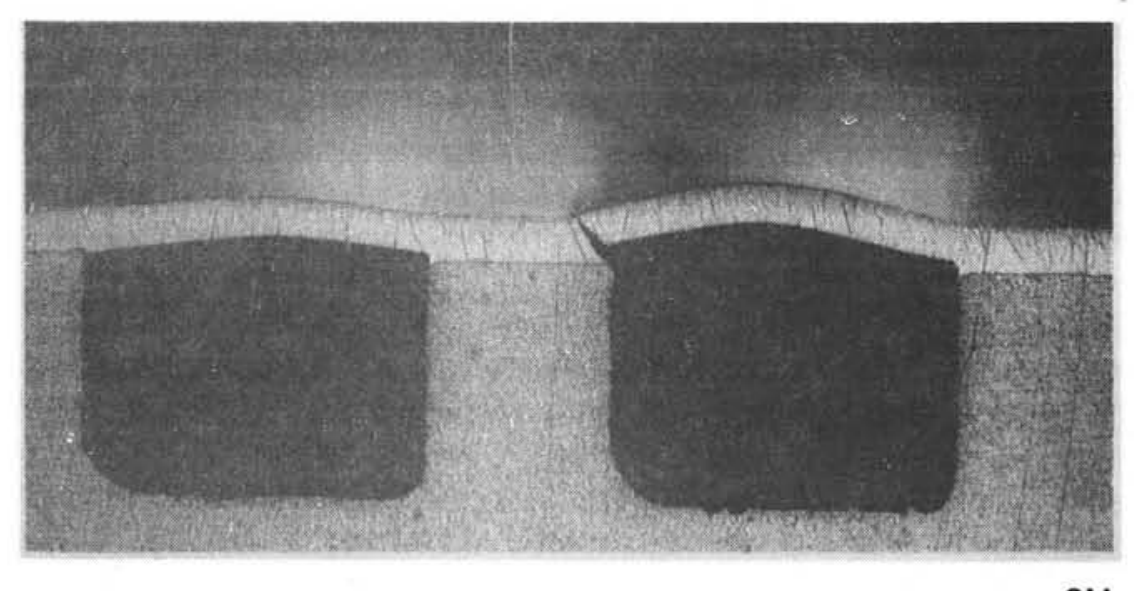

Figure 4. Test Part After Burst Testing 
Phase 2 - Repair of Full-Size Part

$\underline{\text { As-Received Condition }}$

The part as received from LRC is shown in Figure 1. Two incisions had been made approximately 180 degrees apart in the $1.52-\mathrm{mm}$-thick $(0.060$ in. ) nickel coating covering the channels. For the most part, these cuts exposed the underlying steel. However, at the smaller diameter end on one side, the incision did not cut entirely through the nickel and approximately 7 channels were not opened (see Figure 5). Nothing was done at SLL to open these particular channels further. One section of the plating on the smaller diameter end of the part had been chipped off during machining or handling (see circled region in Figure 1). It was decided that this section should also be repaired by plating along with the exposed channel regions.

Before shipping the part, LRC personnel had determined by pressure checking that the nickel bond to the steel was capable of withstanding 3.4 $\mathrm{MNN} / \mathrm{m}^{2}$ (500 psi).

\section{$\underline{\text { Repair Process }}$}

Aluminum shims, $0.76-\mathrm{mm}(0.030 \mathrm{in}$.$) thick, were wedged into the$ exposed open channels (Figure 6). The region to be repaired was then coated with polyvinyl alcohol (PVA), because PVA forms a film which is water-soluble but not soluble in the solvent used in the silver-conductive epoxy which was subsequently used to plug any openings remaining between the aluminum and the bulk of the part. After the epoxy had been allowed to cure, the part was vigorously scrubbed to remove the PVA and any epoxy which had oozed out onto the aluminum, steel, or nickel surfaces.

It was decided to use the part as its own tank for nickel plating. Therefore, the bottom had to be sealed to prevent loss of solution and the top had to be extended, since plating was required right up to the top edge of the part. The extension and the bottom seal were made of plastic, as shown in Figure 7.

The interior of the part was masked with stop-off lacquer*, except for $7.6-\mathrm{cm}$-wide ( 3 in.) bands in the regions to be repaired. The purpose of this step was to prevent plating from building up in those areas in which it was not needed. Sulfur-depolarized nickel anode chips placed in titanium baskets bagged with cloth were suspended directly adjacent to the areas to be plated (Figure 8). A pump and filter were used to purify the solution continuously and also to provide a means of solution agitation. Figures 8 and 9 show a polyvinyl chloride tubing flow device designed to allow for plating solution to impinge directly on the regions to be plated.

* Translucent Maskant 1-2021-66, Organocerams, Santa Ana, CA. 


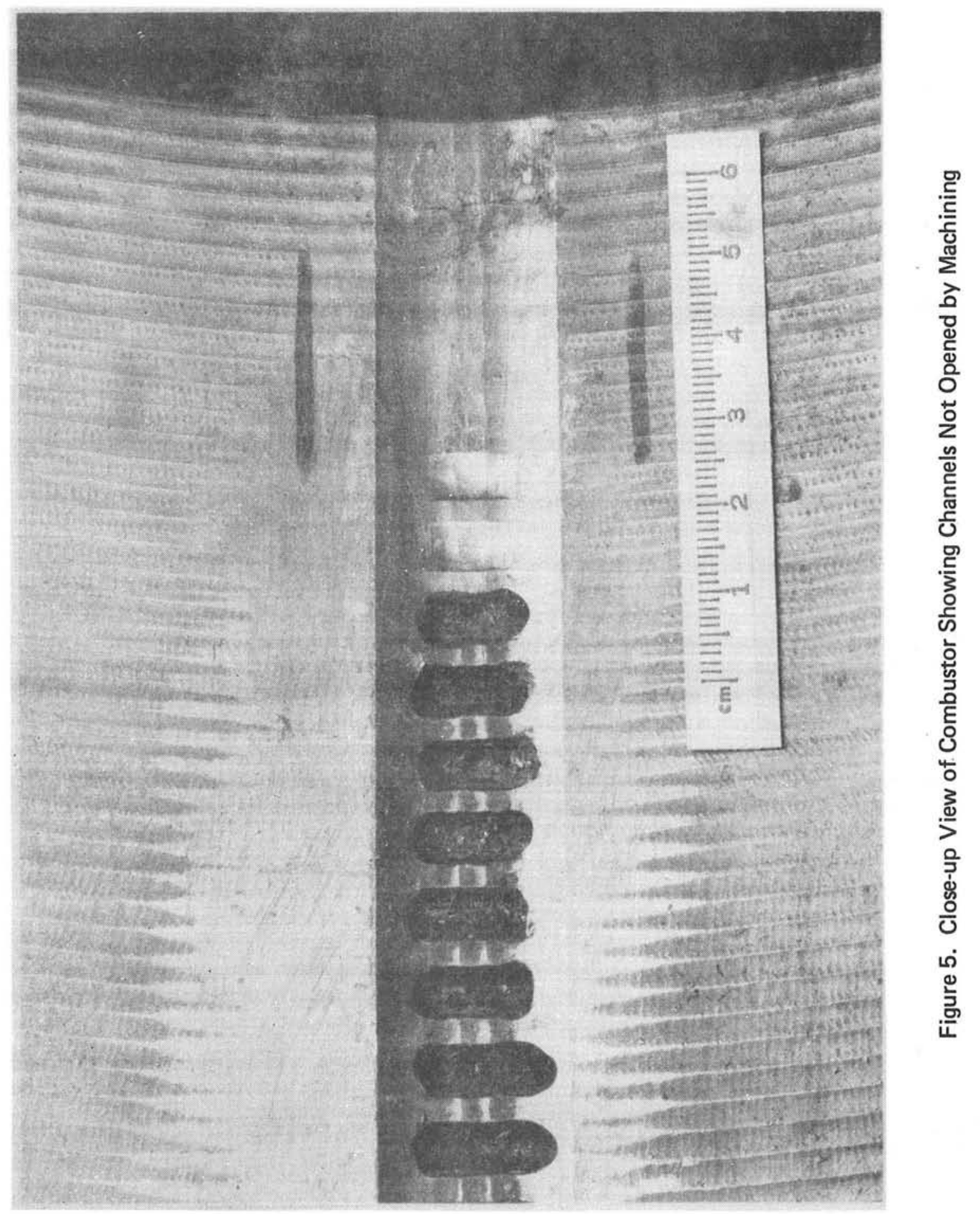




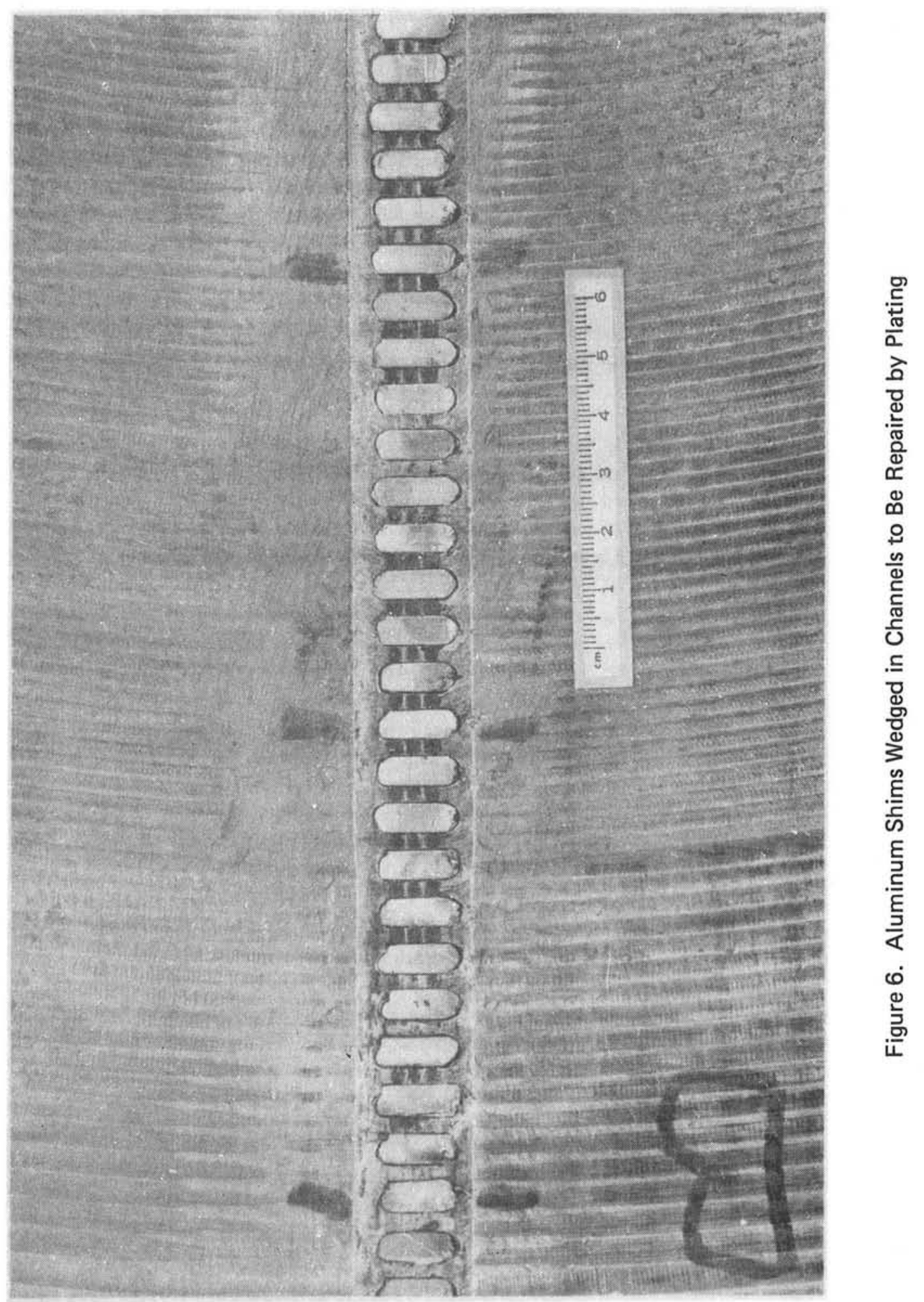




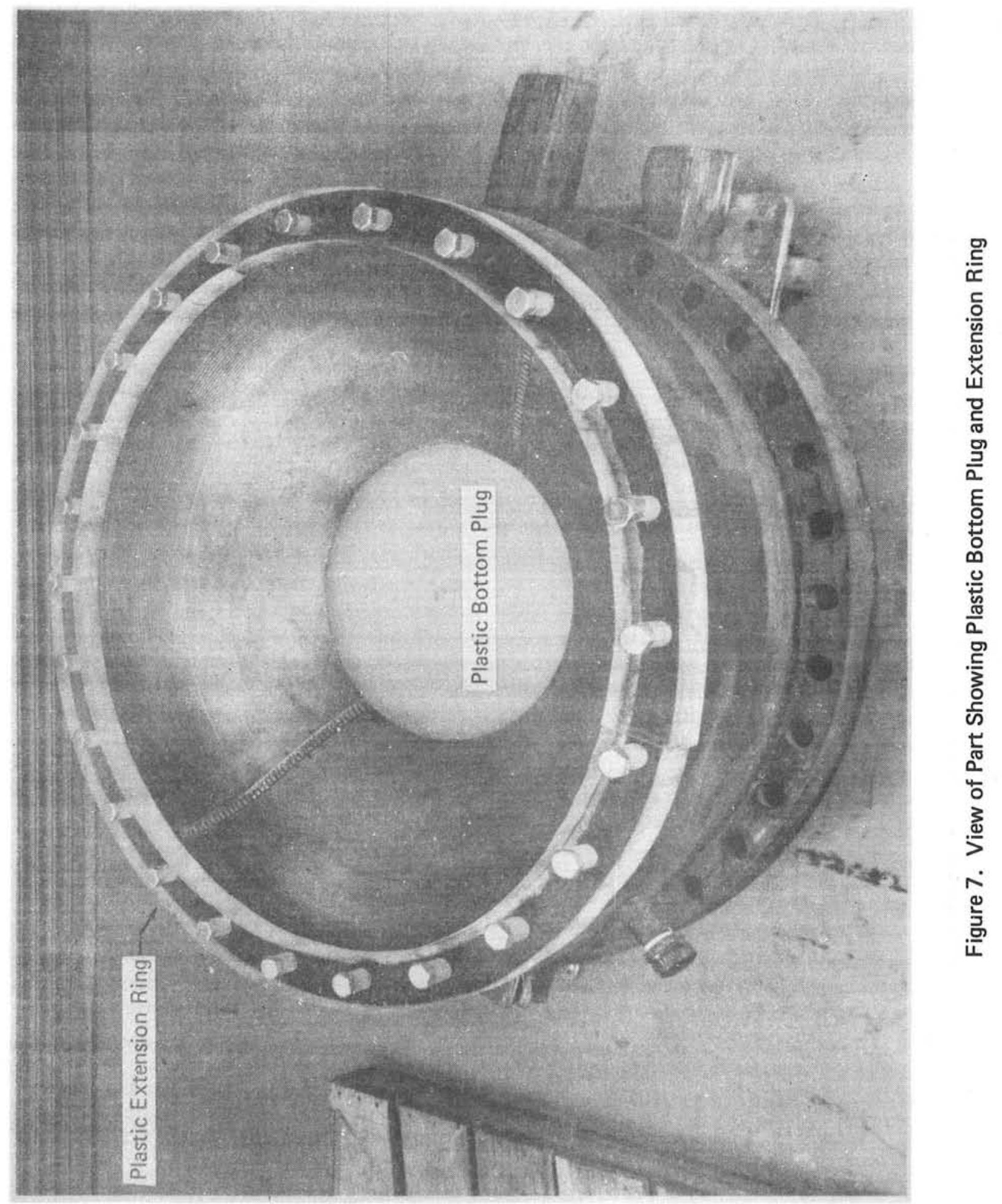




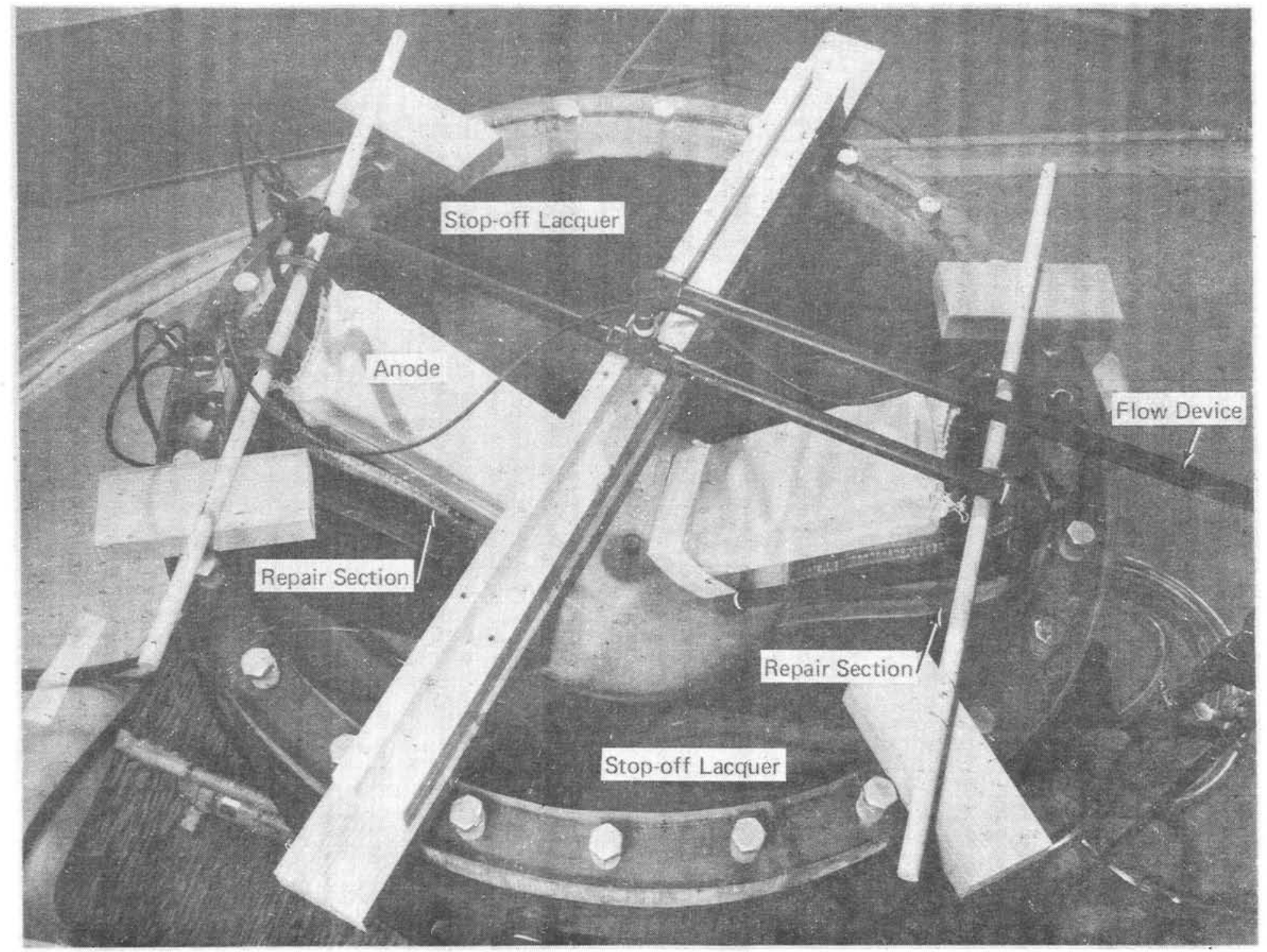

Figure 8. Interior of Part Before Filling With Plating Solution 


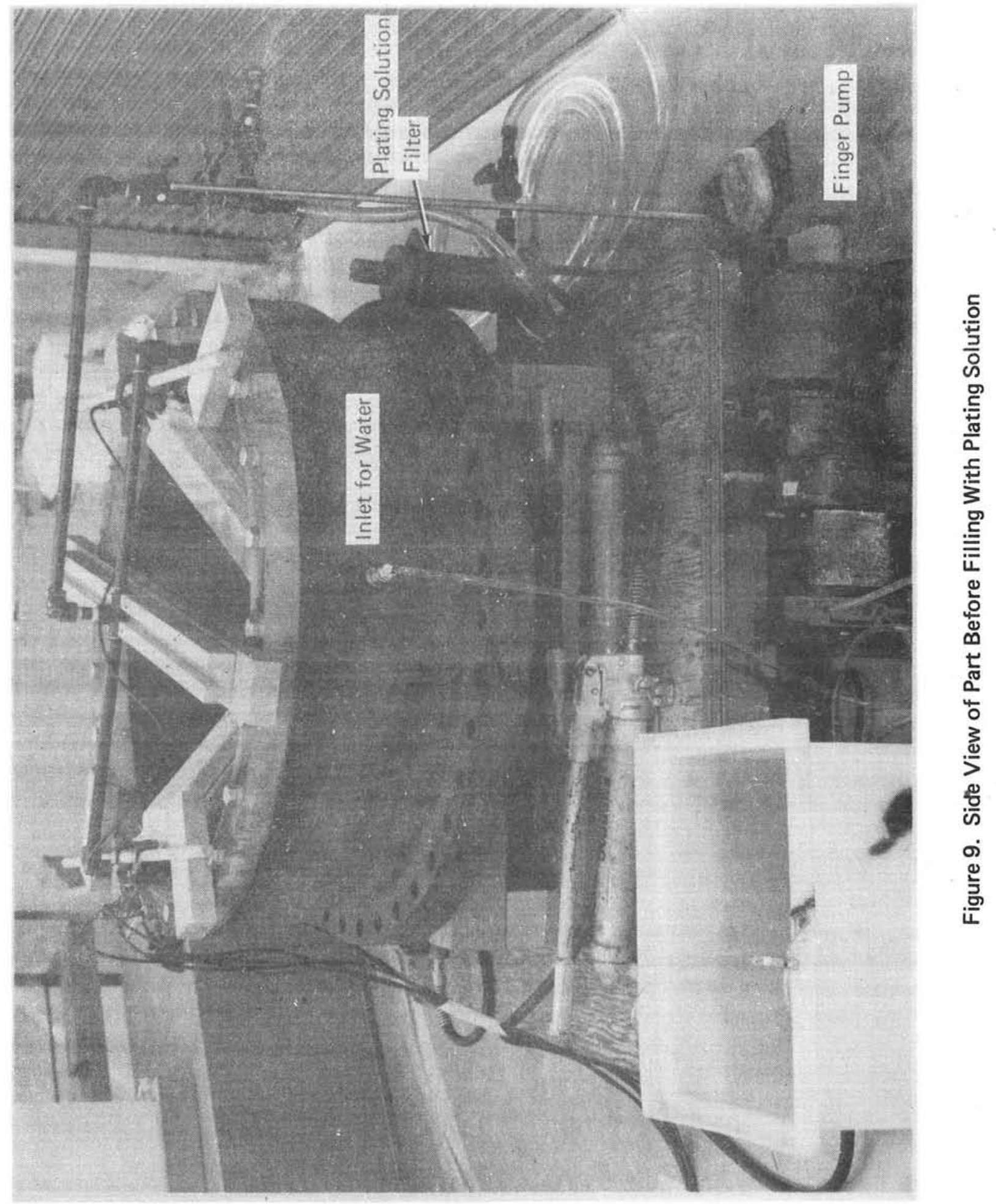


To keep the interior channels clear of solution from the cleaning and . plating steps, water was occasionally flushed through them by means of a finger pump shown in Figure 9. Figure 10 shows the part during plating, including the plating solution filter pump (lower right corner), the plastic balls used for minimizing solution evaporation, and bottle solution levelers for maintaining constant volume. The rectifiers used to provide direct current are shown in the background in Figure 10.

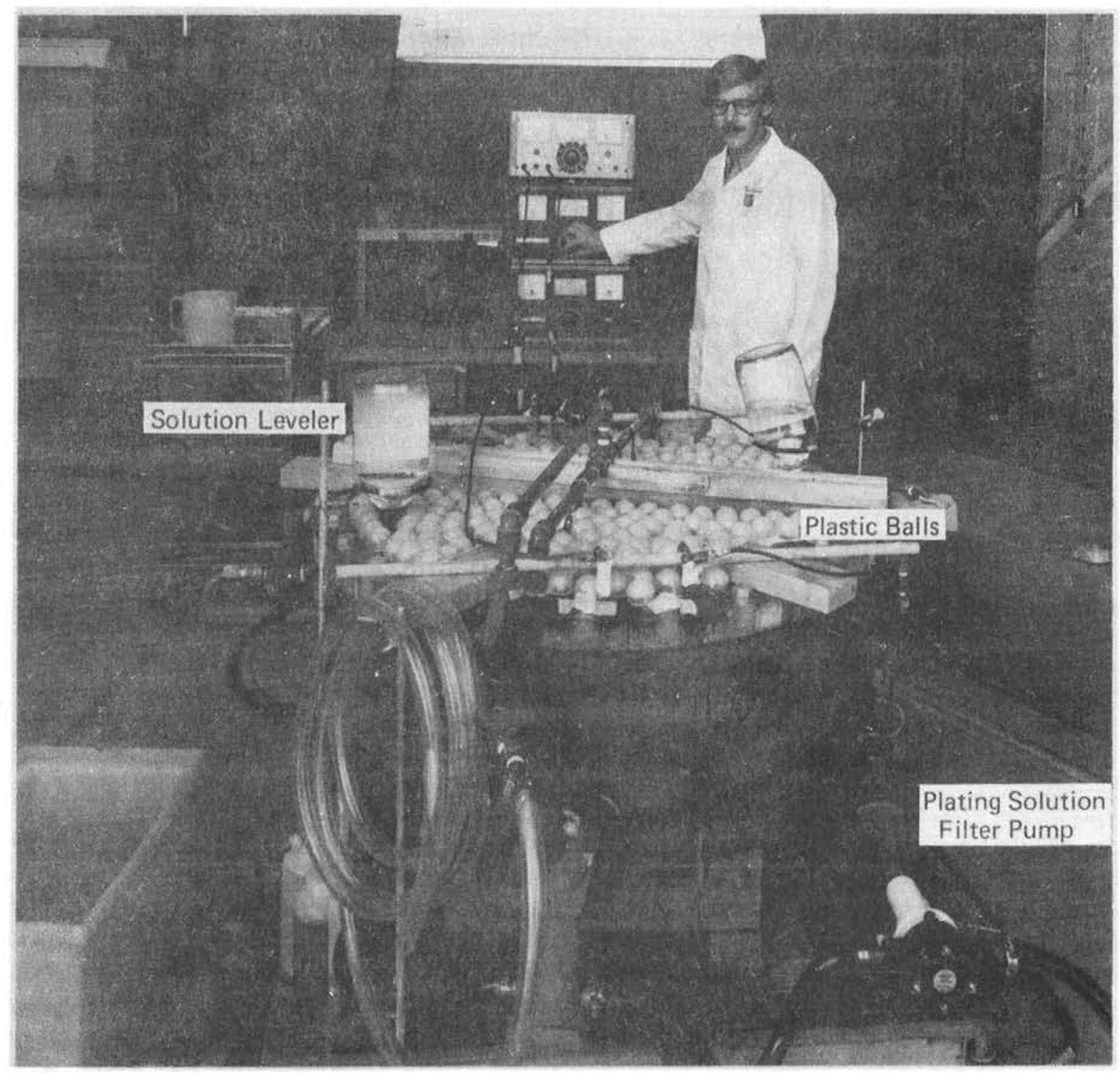

Figure 10. View of Part During Plating 
$\underline{\text { Procedure for Cleaning and Nickel Plating of Nozzle }}$

The following steps outline the procedures used on the nozzle:

1. Scrubbed twice with Alconox and pumice to remove PVA and oxidation products on nickel.

2. Scrubbed an additional 3 times with pumice and rinsed.

3. Treated anodically at $1080 \mathrm{~A} / \mathrm{m}^{2}\left(100 \mathrm{~A} / \mathrm{ft}^{2}\right)$ for 4 minutes in 50 percent sulfuric acid at $32^{\circ} \mathrm{C}$ (lead cathodes were used). This step did not completely clean the rust from all exposed steel regions; therefore, the part was given an additional 4minute anodic treatment in 50 percent sulfuric acid. It was then possible to remove the remaining rust particles with a wire brush.

4. Rinsed with tap water and then with de-ionized water.

5. Given a nickel strike in solution containing $80 \mathrm{~g} / 1$ nickel and $150 \mathrm{~g} / 1$ sulfamic acid at $49^{\circ} \mathrm{C}$ and $540 \mathrm{~A} / \mathrm{m}^{2}\left(50 \mathrm{~A} / \mathrm{ft}^{2}\right)$. Since some areas of the steel did not appear to be coated with nickel, this step was repeated. Upon completion of the second striking operation, the part looked much better.

6. Nickel strike solution was withdrawn from part and replaced with nickel sulfamate solution, with no intermediate rinsing. Plating was begun at $216 \mathrm{~A} / \mathrm{m}^{2}\left(20 \mathrm{~A} / \mathrm{ft}^{2}\right), \mathrm{pH} \mathrm{3.8}$, surface tension 33 dyne $/ \mathrm{cm}, 40^{\circ} \mathrm{C}$. Composition of the solution was $80 \mathrm{~g} / 1$ nickel, $450 \mathrm{~g} / 1$ nickel sulfamate, $40 \mathrm{~g} / 1$ boric acid, and $1.0 \mathrm{~g} / 1$ nickel chloride. Anodes were sulfur-depolarized nickel.

The part was plated for 12 days, the solution was then removed from its interior, and the plating buildup was measured. Thickness of the plating was approximately $3.0 \mathrm{~mm}(0.120 \mathrm{in}$.), which was about $1.5 \mathrm{~mm}(0.060$ in.) greater than that of the nickel on the regions of the part not subject to repair. The stop-off lacquer which had been used to prevent plating in the areas not in need of repair was then removed. During this step an interesting observation was made. The side of the lacquer in contact with the nickel exhibited a silvery metal-like film upon removal from the part (see Figure 11). Chemical analysis revealed this film to be nickel. Since the part had been thoroughly scrubbed and cleaned prior to application of the stop-off material, this occurrence could not be explained. 


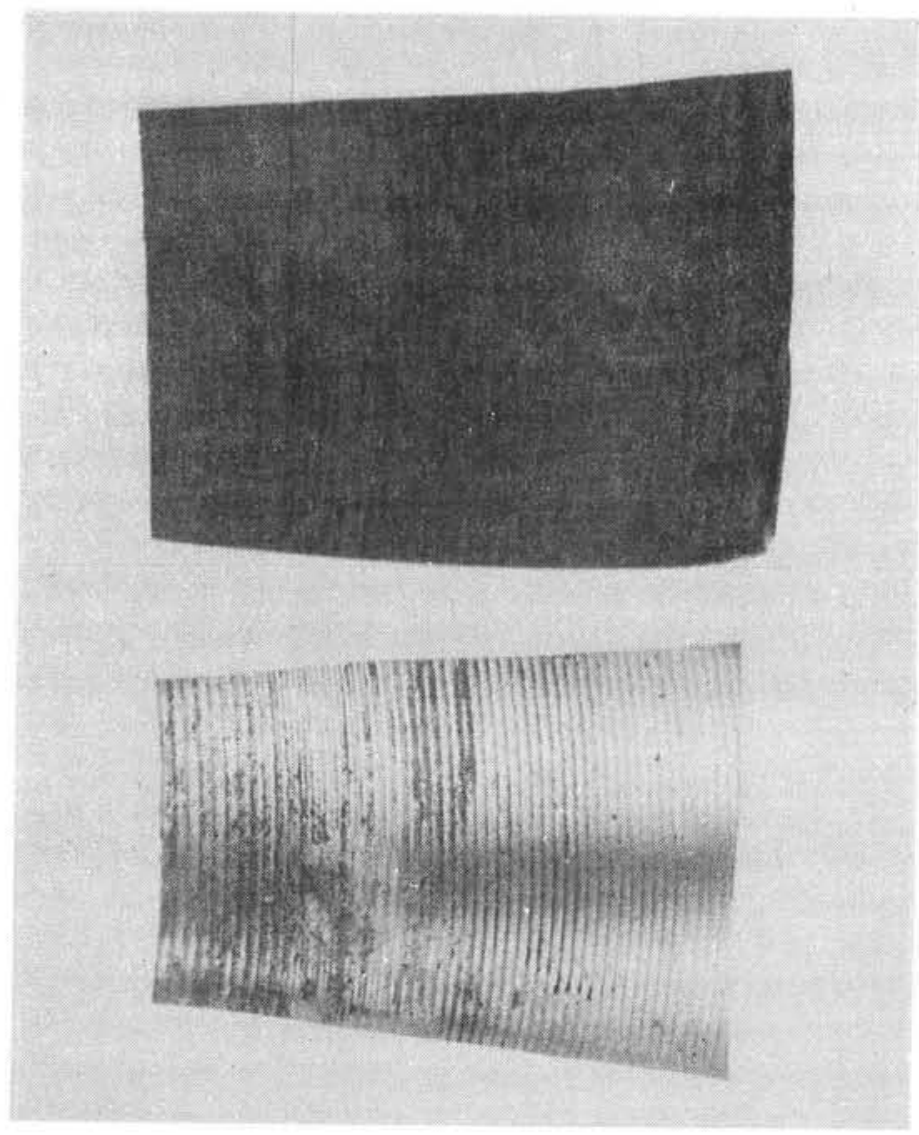

Top Side

Bottom Side

(in contact with nickel)

Figure 11. Stop-off Lacquer Removed From Part

Caustic solution was then pumped through the coolant channels to dissolve the aluminum strips which had been wedged over the channels prior to repair plating. This step required the surprisingly long time of 60 hours, probably because of the mass of the part. Upon completion of this step, the part was flushed with water, the water was removed, and the part was then heated at $316^{\circ} \mathrm{C}$ for 24 hours to help ensure the integrity of the plated bond. Once again the channels were filled with water, and this time the part was subjected to a hydrostatic pressure of $3.4 \mathrm{MN} / \mathrm{m}^{2}$ (500 psi). No signs of leakage were evident, so the part was readied for shipment to LRC for machining to final tolerance. 


\section{UNLIMITED RELEASE}

INITIAL DISTRIBUTION:

NASA Langley Research Center

Hampton, VA 23665

Attn: J. W. Allred

T. A. Blackstock

J. D. Buckley

E. B. Geer

W. K. Gerdes

R. L. Goble

D. R. Hayes

H. N. Kelly

J. C. Miller

E. K. Smith

B. T. Updike

G. D. Ware

B. H. Wilfang

W. A. Wright

R. S. Wilson, 3620

S. D. Holmes, 3622-3

R. S. Claassen, 5800

IM. J. Davis

T. B. Cook, Jr., 8000; Attn: L. Gutierrez, 8100

C. H. DeSelm, 8200

W. C. Scrivner, 8400

B. F. Murphey, 8300

R. H. Meinken, 8310; Attn: R. W. Mar, 8313

H. J. Saxton, 8314

D. R. Adolphson, 8312

J. W. Dini, 8312 (5)

H. R. Johnson, 8312

Technical Publications and Art Division, 8265, for TIC (2)

F. J. Cupps, 8265/Technical Library Processes Division, 3141

Technical Library Processes Division, 3141 (4)

Library and Security Classification Division, 8266 (5) 